OPEN ACCESS (C) (1) (2)

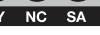

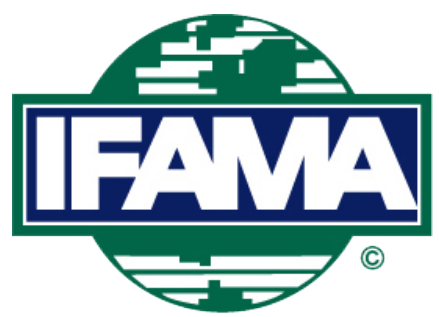

International Food and Agribusiness Management Review

Volume 20 Issue 5, 2017; DOI: 10.22434/IFAMR2016.0171

Received: 8 November 2016 / Accepted: 21 May 2017

\title{
Exploring the applicability of a sustainable smallholder sourcing model in the black soybean case in Java
}

RESEARCH ARTICLE

\author{
August R. Sjauw-Koen-Fa ${ }^{\oplus a}$, Vincent Blok ${ }^{\mathrm{b}}$, and Onno Omta ${ }^{\mathrm{c}}$ \\ ${ }^{a}$ PhD Candidate, ${ }^{b}$ Associate Professor and ${ }^{c}$ Professor, Management Studies Group, School of Social Sciences, \\ Wageningen University, Hollandseweg 1, P.O. Box 8130, 6700 EW Wageningen, the Netherlands
}

\begin{abstract}
Food and agribusiness multinational enterprises are redesigning their sourcing strategies to tap into the underused food production potential of small-scale farms in a way that improve farmers' livelihood. The problem is that current widely applied sourcing models do not include improvement of livelihood of the producers/farmers. The present article explores the applicability of a sustainable smallholder sourcing model with a list of critical success factors, in which business objectives and corporate social responsibility perspectives are combined. To this end, the black soybean supply chain in Java/Indonesia is studied. It was found that the black soybean case can be conceptualized by the sourcing model. Most of the critical success factors were present, but also some differences were identified. The differences enable to fine-tune some critical success factors. The sustainable sourcing model can help in (re-)designing sourcing strategies to secure sustainable and more equitable supply from small-scale farmers from a business perspective.
\end{abstract}

Keywords: agribusiness, CSR, smallholder inclusion, sustainable sourcing, value chain JEL code: O13, Q13, Q01, Q02

\footnotetext{
${ }^{\circledR}$ Corresponding author: august.sjauw-koen-fa@wur.nl
} 


\section{Introduction}

The challenge in meeting the increasing global food demand (FAO, 2009) is that food supply must be achieved in an era that is characterized by resource constraints imposed by planetary resource boundaries and climate change, while dietary patterns are shifting and consumers concerns of food production are intensifying. In addition, corporate actors are increasingly called upon to play a proactive role in solving pressing global challenges such as food security, climate change and poverty reduction (e.g. UN Sustainable Development Goals 2015-2030).

In response to the challenging global food demand, food and agribusiness multinational enterprises (F\&A MNEs), such as Unilever, Hershey, Mars, Mondelez, Cargill, Ferrero and Nestlé, are redesigning their sourcing strategies to tap into small-scale farms (smallholders) in developing and emerging economies. This relates largely to commodities such as cocoa, coffee, bananas, tea, and cotton. The F\&A MNEs' aim is to secure sustainable supply in a way that includes improvement of livelihood/economic welfare of smallholders.

Smallholders in developing and emerging economies, however, face productivity, product quality and transactional constraints in their effort to access high value-adding food markets (e.g. London et al., 2010; Rivera-Santos and Rufin, 2010). To overcome these constraints, smallholders need to become more advanced. F\&A MNEs can potentially help smallholders with these challenges, because of their dominant position in agricultural value chains (e.g. Reardon et al., 2009; Rossignoli and Moruzzo, 2014; Sjauw-Koen-Fa, 2010). The problem is that the conventional sourcing strategies by F\&A MNEs mainly focus on complying with consumers' concerns regarding environmental and societal issues of production (e.g. Bush and Bain, 2004; Henson and Humphrey, 2009; Trienekens et al., 2012), rather than on improving farmers' livelihood/economic welfare. This raises the question how conventional sourcing strategies by F\&A MNEs from smallholders can address smallholders' livelihood improvement simultaneously with other business objectives.

We have found several studies assess the impact of conventional sourcing models on farmers' livelihood (e.g. Blackman and Rivera, 2011; Dragusanu et al., 2014; Jaffee and Henson, 2004; Ruben and Fort, 2011; Rueda and Lambin, 2013) and some empirical case studies scrutinize particular aspects of smallholder interest by F\&A MNEs (Alvarez et al., 2010; Perez-Aleman and Sandilands, 2008). The question remains how F\&A MNE's can best include smallholders' interest in their sourcing practices to secure a sustainable and more equitable supply, while maintaining competitive advantage. This has not been studied extensively yet. In order to find an answer to this sourcing question, Sjauw-Koen-Fa et al. (2016) have developed a Sustainable Smallholder Sourcing model (3S-model) with a list of critical success factors, based on a literature review, in which the delivery of value for improvement of livelihood/economic welfare to smallholders is integrated.

The objective of this research is to explore the applicability of this smallholder sourcing model by using primary data from a value chain analysis of the black soybean supply chain of an F\&A MNE in Java. The value chain analysis was conducted in November-December 2013 aimed at learning how the F\&A MNE can do business with smallholders in a way that improves the farmers' livelihood (Tait, 2015). The black soybean supply chain in Java was scaled, providing longitudinal data (2007-2013), proved to work and had produced progressive results. As such, this case is considered as a best practice example for exploring the applicability of the developed Sustainable Smallholder Sourcing model.

In the next section, the framework of the developed Sustainable Smallholder Sourcing model with the list of critical success factors (CFSs) will be introduced, followed by the materials and methods section. Finally, the case findings of the study are presented and the lessons learned are discussed and concluded. 


\section{Introduction to the Sustainable Smallholder Sourcing model}

As we want to explore the applicability and the dynamics of the Sustainable Smallholder Sourcing model (3S-model) with the list of CFSs by studying a best practices empirical case in the present article, we first explain the framework of the Model in this section.

The conceptual elements of the 3S-model are:

1. 'Upgrading' (Humphrey, 2004; Humphrey and Schmitz, 2002), which is defined as a transition of firms/ smallholders to higher value added activities or interventions in production to improve technology, knowledge and skills in order to increase the benefits or profits deriving from the participation in regional or global production networks.

2. 'Supplier development program' (Hahn et al., 1990; Watts et al., 1995), which is defined as long-term cooperative efforts between a lead food firm and its suppliers to upgrade smallholder farming systems to secure sustainable supply from a business perspective and improving smallholder livelihood at the same time.

3. 'Global value chain governance structure' (Gereffi et al., 2005), which is defined as non-market coordination. We used their framework to determine the emerging coordination combination with the characteristics of smallholder supply chains from Riisgaard et al. (2010), in order to determine the best governance structure to coordinate smallholder supply chains for supplier developed by F\&A MNEs. This is the Captive governance type in which supply chain actors are locked in for upgrading smallholder farming system by the lead firm.

The CSFs are based on Supply Chain Management literature on the domains of sourcing/strategic purchasing and buyer-supplier relationships, and the literature on Subsistence Market and Bottom of the Pyramid on the domains of competitive and institutional environment, networks, and farmer business models. The aim was to identify leverage points/synergistic connections between MNE (the buyer), sourcing strategies (top-down approach of the supply chain), and small-scale farmer business models (bottom-up approach of the supply chain). Enabling us to define the six sub-questions based on the synergistic connections that were found.

Frameworks that provide a complete overview of the challenges of supply chain management and the bottom of the economic pyramid BOP that were used to identify leverage points/synergistic connections for smallholder inclusion in high value-adding supply chains were:

- For the supply chain management domains: the research framework of Chen and Paulraj (2004) and Carter and Rogers (2008).

- For the BOP domains: The BOP producers constraints frameworks of London et al. (2010) and Rivera-Santos and Rufin (2010).

Figure 1 represents the framework of the 3S-model. The 3S-model consists of 6 building blocks of which F\&A MNE, intermediaries, smallholders and Partnership are the core, while the other two building blocks are control variables.

The sourcing process of sustainable smallholder supply consists of two activities: (1) the buying process in the supply chain (the axis 'F\&A MNE - Intermediaries - Smallholders'); and (2) the upgrading process in the supply chain (the partnership consisting of F\&A MNE, intermediaries and input suppliers). In this model, government, donor, public bodies, Non-governmental organizations (NGOs) and private foundations supporting the upgrading of the smallholder farming system can join in the partnership. The building block 'livelihood improvement smallholders' represents the impact of the 3S-model.

The CSFs which should leverage external and internal organizational challenges of sustainable smallholder inclusion by the F\&A MNE, are located at the conjunctions of the chain 'Partnership - Smallholder farming system' and 'Partnership - F\&A MNE', respectively. There are 5 external (outside the F\&A MNE) and 2 internal organizational (within the F\&A MNE) critical success factors: 


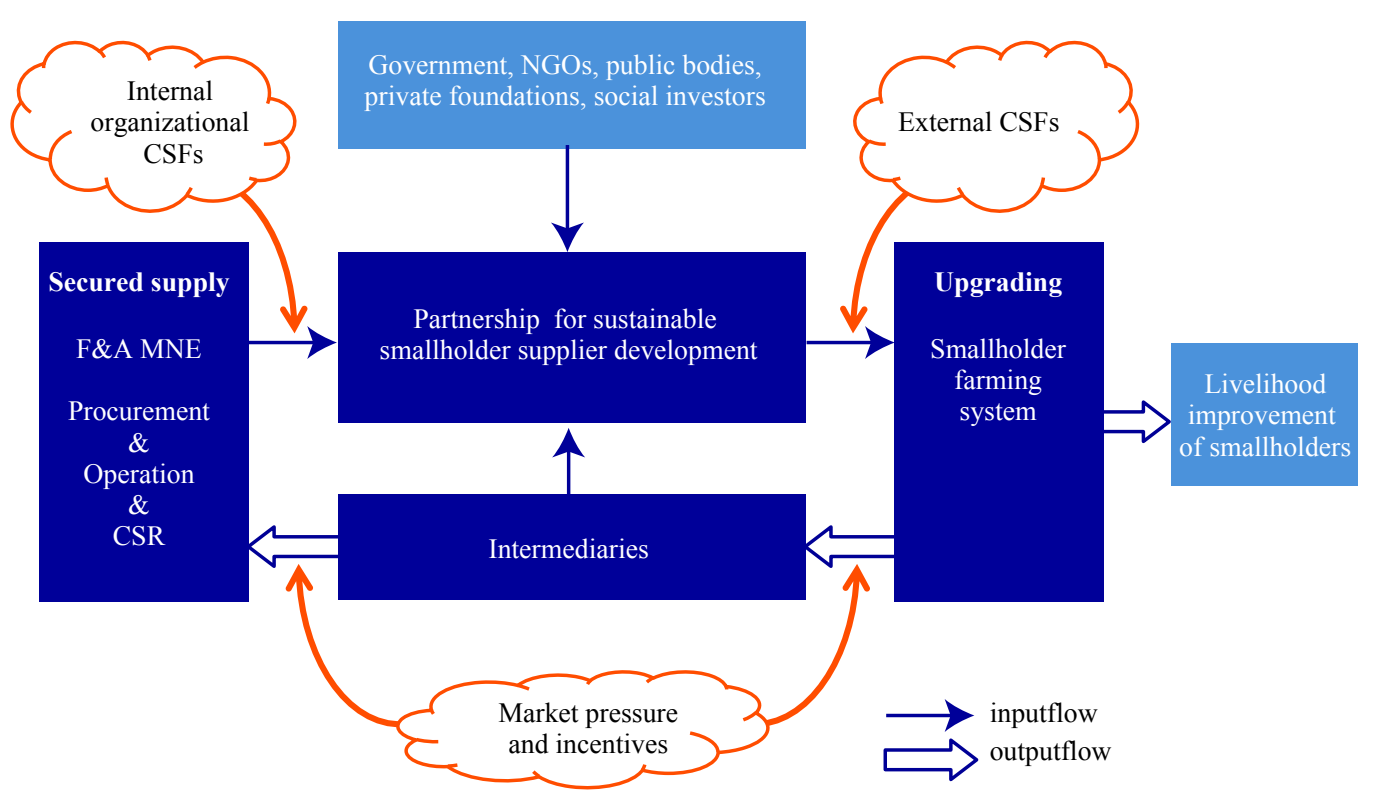

Figure 1. Sustainable Smallholder Sourcing model (3S-model) (Sjauw-Koen-Fa et al., 2016). NGO = Nongovernmental organization; $\mathrm{CFS}=$ critical success factor; F\&A MNE = food and agribusiness multinational enterprises; CSR = corporate social responsibility.

- External organization CSFs:

- CSF 1: selected smallholders are commercial/market-oriented Smallholders that are potentially able to adopt upgrading interventions to meet F\&A MNE's supply requirements from a business perspective successful are commercial/market oriented small-scale farmers. These are according the segmentation of smallholder households of Christen and Anderson (2013) they grow cash crops that are sold usually in local, regional or export markets and have limited access to inputs, financial services and market information.

- CSF 2: building partnership for upgrading

Building a sustainable smallholder supply chain is a long term process that needs to be a cooperative one, which is based on partnership-like and long-term contracts to achieve mutual interest, rather than transactional 'buyer-seller' relationships that are driven by bargaining power and shortterm contracts to achieve quick-wins at low cost by the buyer (Monczka et al., 1998; Trent and Monczka, 2002). Therefore, F\&A MNEs need to collaborate with non-traditional actors, such as NGOs', development and governmental agencies, and social investors, as partner and facilitator in the companies' smallholder supply chains. The aim is to bring public and private resources and capabilities together which are needed to upgrade smallholder farming systems effectively (e.g. Hahn and Gold, 2013; London et al., 2010) and to generate relational rents spread over the supply chain network (Dyer and Singh, 1998).

- CSF 3: building a captive governance structure based on a cooperative 'buyer-seller' relationship To include smallholders effective in high value-adding supply chains, F\&A MNEs need to get closer to smallholders in collaboration with supply chain partners, that are willing to co-invest resources and time, share risks and rewards and maintain relationships over a longer period of time (Krause and Ellram, 1997; Landros and Monczka, 1989). The 3S-model proposes that as lead firm, F\&A MNEs can best apply a captive governance structure (Gereffi et al., 2005) to lock-in all supply chain actors for upgrading smallholder farming system, based on a cooperative rather than a transactional 'buyer-seller' relationship (Hahn et al., 1990; Landros and Monczka, 1989; Mohr and Spekman, 1994). 
- CSF 4: building effective producers' organizations

A producers' organization (PO) is based on the principle that acting collectively improves the position of its members, such as smallholders, and creates growth opportunities in farm productivity and income. They can fit together activities of sellers (farmers) and buyers (traders and processors) to more effectively meet market requirements than smallholders can achieve individually. Areas in which POs can play a role in strengthening the coordination in smallholder supply chains are: reducing transaction costs and marketing risks, enabling collective action and facilitating access to finance (e.g. Chambo, 2009; Onumah et al., 2007; Torero, 2011).

- CSF 5: providing access to finance to smallholders

In many developing countries financial markets are imperfect because of high transaction costs and information asymmetries. These imperfections are likely to be binding on smallholders that lack collateral credit history and connections. However, access to affordable financial services is essential in order for smallholders to meet investment and working capital requirements, and other financial services such as insurance to cover risk and savings, to unlock their potential (Chalmers et al., 2006; IFC and GPFI, 2011; Miller and Jones, 2010; Sjauw-Koen-Fa, 2012).

- Internal organizational CFSs (within the F\&A MNE) are:

- CSF 6: presence of a clear smallholder sourcing strategy by the F\&A MNEs Firms have different responses to social responsibility and social issues such as smallholder inclusion. This refers to a firm's corporate commitment and capacity, such as mechanisms, procedures, arrangements, behavioral patterns, sustainability codes and standards to anticipate social issues (e.g. Gold et al., 2013). Social responsiveness of firms can range from 'doing nothing' to 'doing much' regarding CSR (Caroll, 1979; Maignan et al., 2002; Van Tilburg et al., 2012). In the supply chain literature, the involvement and commitment of the top management has been emphasized, because they understand best the needs of supply chain management as they have the most knowledge of the firm's strategic imperatives to remain competitive in the market place (Hahn et al., 1990; Monczka et al., 1998). The presence of a proactive CSR strategy, including a responsible supplier guide and sustainable agricultural codes, which is supported by the top management, is a critical precondition for long-term investments in sustainable smallholder supply (Gold et al., 2013; Monczka et al., 1998).

- CSF7: use of Cross-functional sourcing teams

The challenge is that within large firms profit driven short term business activities and policy/ strategic driven long term CSR activities are operating in different structures. However, the sustainability and CSR strategy should be integrated into core business operations, activities and products and services of the firms (e.g. Blok et al., 2013; Spence and Bourlakis, 2009). The use of Cross-functional teams, led by Procurement and Operation and including CSR of the F\&A MNE, may help to harmonize organizational values, routines and resources, and to interact effectively with supply chain counterparts (Driedonks et al., 2014; Olsen and Boxenbaum, 2009; Trent and Monczka, 1994).

\section{Materials and methods}

\subsection{Research setting}

Soybeans and sweet soy sauce in Indonesia by Unilever Indonesia

In Indonesia close to $90 \%$ of the soybeans are processed into food products 'tahu' and 'tempe', which are the main source for proteins, vitamins and fat for low-income households in Indonesia. A smaller amount is used for production of soy milk, sauces and other traditional Javanese food products. Per capita consumption of soybeans of Indonesia has increased significantly, while domestic soybean production has been declining in the past decades, due to large import of cheaper (yellow) soybeans most from the USA. This is possible because Indonesia applied a liberal trade policy (e.g. Dartanto et al., 2011). The lack of infrastructure to support government initiatives and farmers' lack of access to better farming technology are seen as major 
causes for the souring of domestic production. Moreover, import soybeans were preferred by the local food processing industry, because they had a better and more constant quality than domestic grown soybeans. Consequences of the liberal trade and 'cheap' basic food security policies of the Government was that the involvement of the government in local agricultural supply chains development, such as black soybean production, remains at arm's length. They provide mainly general agricultural support, such as extension services, empowerment of cooperatives and facilitating sustainable agriculture platforms.

Unilever Indonesia is a subsidiary of Unilever that produces and sells a number of brands locally. It had implemented the fundamentals of corporate social responsibility (CSR) from the early 1970s onwards, which is basically focused on market and community development support (Urip, 2010). In 2000, Unilever Care Foundation Indonesia (Unilever CSR) was established in Indonesia to strengthen the Unilever Indonesia's commitment to sustainable development of Small and Medium Enterprises in Indonesia, while maintaining a competitive edge, i.e. CSR became an integral part of Unilever Indonesia 's business strategy for Indonesia. Unilever Indonesia is helping small-scale paddy famers in Java to produce black soybeans of a high and constant quality used as key ingredient of sweet soy sauce. The specific taste of the black soybeans, the traditional recipe and the use of local small-scale paddy farmers makes it possible to advertise and sell the sweet soy sauce to local supermarkets.

\section{- Historical background of the black soybean supply chain}

In 2001, the Unilever Indonesia acquired a majority stake in a Javanese company producing a regional brand of sweet soy sauce for the Indonesia market. This brand has maintained its classic taste due to the consistent high-quality taste of locally produced black soybeans. It was recognized that the supply of black soybean would not be enough to meet the growing demand of the brand sweet soy sauce, because many smallholders in Indonesia switched to other crops due to the low price of imported yellow soybeans. To solve this problem, the Unilever Indonesia chosen to develop its own black soybean supply chain of smallscale paddy farmers in Java, in addition to still purchasing additional black soybean from selected/qualified regional commodity traders.

However, the small-scale paddy farmers needed to be trained in cultivating black soybean according to good agricultural practices and access to inputs. In 2002 a pilot upgrading farm program with two cooperatives including 12 small-scale paddy farmers has started, and since 2003 the University of Gaja Mada (seed-supplier) has enter into a strategic partnership with Unilever Indonesia providing guidance on how to grow black soybean by paddy farmers and for breeding an improved black soybean variety. They had also selected a high yield variety of black soybean (Malika) that became a cornerstone of the upgrading program. A partnership consisting of Seed-suppliers and selected cooperatives from East and Central Java (Cooperatives) was formed and a program to upgrade small-scale paddy farmers to grow black soybean on contract base was set up.

The period 2002-2007 is seen as the pilot phase of the black soybean supply chain. Around 2007 about 5,000 farmers from eight cooperatives were participating in the planting of black soybean, covering an area of about 1,200 hectares on Java. They contributed 10-20\% of the black soybean demand in the period, while the remaining quantity was purchased from regional commodity traders operating in other areas in Indonesia (Hasibuan-Sedyono, 2010). By 2007 the black soybean supply chain was scaled to a full commercial level. Unilever Indonesia became full owner of the soy sauce company and Malika was certified by the Indonesian authorities and became a cornerstone of the black soybean supply chain. The present study focused on the period 2008-2013 which is the upscaling phase of the black soybean supply chain. 


\section{- Case selection criteria}

The black soybean supply chain in Java of Unilever Indonesia was selected to study the applicability of the 3S-model because:

1. This case study, which includes a value chain analysis, was part of a broader joint research program Sunrise 2.0, commissioned by Unilever (one of the largest consumer goods company of the world with a clear proactive CSR strategy (Van Tilburg et al., 2012), and Oxfam (an international confederation of a number of NGOs working together with partners and local communities). The aim was to learn how Unilever can do business with smallholders in a way that improves the smallholders' livelihood. The research approach included that Unilever viewed smallholder supply chains top-down (from F\&A MNE's perspectives), while Oxfam viewed them bottom-up (from farmer's perspectives). The combined perspectives were also integrated in the used methods, tools and interview questionnaires. The signed Memorandum of Understanding of the Sunrise research project 2010-2015 (see final report of the Sunrise project, available at http://tinyurl.com/y8h4tsqf) was led down that Unilever and Oxfam were funders of the joint research program. Both organizations might use the outcome for their own purposes and interests. These research settings ensured more balanced results of conclusions, rather than in case of dominance of one of the two research partners. Accordingly, the black soybean supply chain in Java provided a unique case for empirical studying the integration of business and CSR perspectives for smallholder inclusion in high value-adding supply chains: it combines the business and CSR perspective which is the basis of the developed Smallholder Sourcing model with the list of critical success factors.

2. As the black soybean supply chain in Java is a scaled supply chain that provided sufficient historical data (2007-2013) and opportunities to review the evolution of the black soybean supplier development program and the governance conditions over a period of time. Moreover, it provided also opportunities to identify and interview all relevant supply chain actors including procurement, operation and CSR managers, farmers, intermediaries, input suppliers, government, field workers and public stakeholders, and to do field observations to verify the accuracy of understanding and consistency of the collected data and information.

\subsection{Methods}

\section{- Research approach}

To explore the applicability of the sourcing model with the list of CSFs, we used the found black soybean supply chain map from the value chain analysis to learn about the partnership model for supplier development and the buying and the upgrading sourcing process including the role of the different actors and trading relationship in the supply chain. We also used the outcome of the black soybean farmer business model to assess the impact of the sourcing model on farmers livelihood. Finally, we match the information and lessons of the black soybean supply chain with the elements of the smallholder sourcing model to explore similarities and difference to draw conclusion about the applicability.

\section{- Back ground field study}

The value chain analysis of the black soybean supply chain was conducted by the lead author in the period June 2013 to April 2014. The desk research consisted of an evaluation of the sourcing strategy and the CSR policy of the Unilever Indonesia, reviewing publications regarding the black soybean sector in Indonesia, and collection of relevant information and data about the supply chain. The field research in Java was conducted in Jakarta and Jogjakarta from 24 November to 4 December 2013. The practical toolkits of the LINK methodology of the International Center for Tropical Agriculture were applied to map the black soybean supply chain and to explore the farmers' business model and to get an indication of the impact of the applied black soybean sourcing model on smallholders' livelihood. 
Before the field research in Java was conducted, the black soybean supply chain were preliminary mapped in cooperation with Unilever Indonesia. The aim was to select and invite participants of all categories of supply chain actors (input suppliers, farmers, cooperatives, region commodity traders, managers of the Unilever Indonesia, government representatives, field workers, NGOs) for a multi-stakeholder workshops, to select interviewees for semi-structured interviews and for a field observations. The number of smallholders (out of about 8,200 distributed across nine areas in Java) that could be invited for the workshop and interviews was limited (in total 17), because they had to come (fly) to Jogjakarta. We selected smallholders that had experience with the black soybean upgrading program for several years, because we primary focus on why smallholders stay in the black soybean program. The assumption we made was that profitability and income security of producing black soybean according to the conditions of the upgrading program are foremost the key consideration to join and to stay in the program. Moreover, farmers were free to join the black soybean supply program, because they can grow other crops such as corn, chili peppers and ground nuts for the market. We cross-checked the impact of the applied black soybean supply program on smallholder livelihoods during the workshops and field visits and by means of personal communication with supply chain actors.

The program of the field research conducted in Java consisted of the following elements:

- A multi-stakeholder workshop with all key stakeholders of the black soybean supply chain including Unilever Indonesia Procurement and CSR managers, Cooperative executives, farmers, seed supplier, field workers, NGO, local government servant of the black soybean supply chain $(n=22)$ was held to explore the (trade) relations and the flow of products, services and payments between stakeholders in order to map the black soybean supply chain. Topics discussed during the multi-stakeholder workshop were: what are the core processes in the supply chain? How is the supply chain organized? Who are the key partners? How do products, payments, services and information flow through the supply chain? What are the external influences that affect the performance of the supply chain?

- A farmers' workshop ( $\mathrm{n}=17)$ to map the farmers' business model. We used the business model canvas exercise to get an indication of cost-revenue structure. In addition, we used the standard cost price calculation of black soybeans that is used to determine the contract price in order to calculate the break-even price of black soybean at farm gate level (Indonesian Rupiah $/ \mathrm{kg}$ ).

- 23 semi-structured interviews with representatives of different categories of stakeholders of the partnership and regional commodity black soybean suppliers were conducted: executives of cooperatives $(n=3)$, Unilever Indonesia-procurement manager $(n=1)$, Unilever Indonesia Operation manager $(n=1)$, Unilever Indonesia-Supplier development manager $(n=1)$, Unilever Indonesia CSR managers $(n=2)$, representatives of the seed supplier $(n=1)$, field assistants $(n=2)$, government extension agents $(n=1)$, women groups $(n=2), \operatorname{NGO}(n=1)$, regional commodity traders $(n=3)$ and farmers $(n=5)$. The aim was to explore each profile and each relationship in contract terms, and all barriers, drivers and success factors, performance indicators, and future perspectives. For each stakeholder category a semi-structured questionnaire was developed (Supplementary Methods S1). All interviews were recorded and transcribed in English. A Bahasa interpreter was hired in case interviewees and participants of the workshops were not able to communicate in English. Reports of the workshops were drawn up and the interviews were transcript.

- A field observation to a cooperative nearby Jogjakarta was paid to get an in-depth view of the organization and the practice such as storage and sorting facilities they provide to farmers. Two executives of a farmers' women group were interviewed to explore the role of farmers' women in the black soybean supply chain.

- A meeting with a delegation of Indonesian Human Rights committee for Social Justice about the black soybean supply program arranged by Oxfam Indonesia in Jakarta.

Practical toolkits from the Sunrise 2.0 research program that were used to explore the impact of the upgrading program of black soybean on smallholder livelihood, were from of the LINK (acronym from 'LINKing' smallholder to markets) methodology was developed by the International Center of Tropical Agriculture (available at: http://tinyurl.com/yb6gaatd): 
- the business model canvas exercise to draw the famer business model during the farmers' workshop;

- the score cart within the New Business Model Principles was filled out in the multi-stakeholder workshop to examine the inclusiveness of the black soybean program.

The aim of the Methodology is to foster inclusive trading relation between farmer organization and formal markets. It has been conducting action research on inclusive business model since 2007.

\section{Case findings}

\subsection{Design of the black soybean supply chain map}

Figure 2 shows the black soybean supply chain map that resulted from the multi-stakeholder workshop and information collected from the interviewees.

There were two supply chains of black soybeans to Unilever Indonesia: (1) the traditional supply from smallholders of other areas to regional commodity traders to Unilever Indonesia; and (2) the new developed supply chain from smallholders (member farms) to Cooperatives to Unilever Indonesia. The latest supply chain has become increasingly the supply source, while the traditional supply chain was used as a leverage to meet total black soybean demand of Unilever Indonesia. The farmer's price and delivery conditions of the black soybeans of both supply chain are equivalent.

In the present study we focused on the development black soybean supply chain of Unilever Indonesia. However, both supply chains are interrelated by the use of a similar price, product quality and delivery conditions. The developed black soybean supply chain consisted of two activities: (1) the buying processes (the axis Unilever Procurement - Cooperatives - smallholders) led by Procurement; and (2) the upgrading

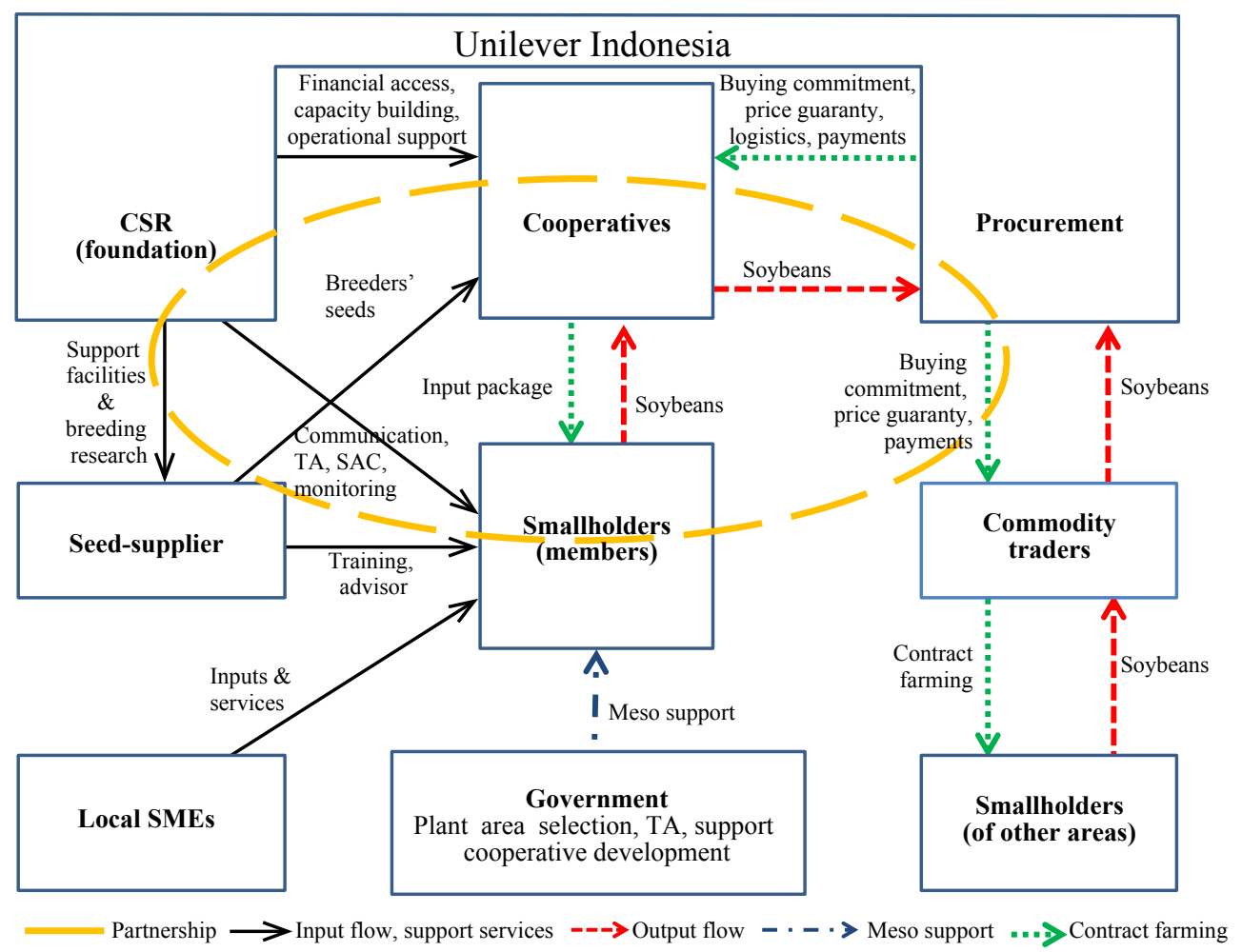

Figure 2. Black soybean supply chain map in Java. SMEs = Small and medium-sized enterprises; TA = Technical assistance; SAC $=$ Sustainable Agriculture Code. 
processes (the partnership consisting of Unilever CSR - Cooperatives - Seed supplier (circle)) led by Unilever CSR, because of their mission to support Unilever Indonesia corporate sustainable development in Indonesia (Urip, 2010: 99-122). The different arrows represent the flow of products, payments and upgrading interventions provided by supply actors during the planting season.

The sourcing process of black soybean started with the calculation of the required beans needed for the next season to produce sweet soy sauce. Buying conditions were: the price was guaranteed before planting and there was a commitment to buy all black soybeans that was produced and had the required quality. With this information, Unilever-CSR consulted Cooperatives and Seed-suppliers to explore how many of the demanded black soybeans could be produced by the smallholders that are small-scale paddy farmers. The outcomes of the assessment and the agreed terms were written down in a Memorandum of Understanding signed by Cooperatives and Seed supplier. Side selling by farmers was not permitted but was not penalized either. Remaining soybeans that the MNE needed for the next season came from selected regional commodity traders that operated in other areas than those operated in by the Cooperatives. These traders had a long standing supply relationship with Unilever Indonesia.

During the planting seasons, field assistants of Unilever Indonesia-CSR were frequently in touch with farmers, and each month a meeting was held with field assistants and cooperatives. One month before the harvest, Unilever Indonesia paid $80 \%$ in advance on sales that allowed them to provide a cash loan to farmers before the harvest and the remaining part was paid shortly after delivery. The total estimated harvest to be delivered was determined by Cooperatives along with Unilever-CSR. After the harvest, the Cooperatives facilitated the collection of the beans, the sorting (by hired women farmers), storage and payment to farmers or farmer groups. Finally, the beans were collected by Unilever Indonesia-Procurement and transported to the soy sauce factory near Jakarta.

The involvement of the government in the black soybean supply chain was on 'arm's length', i.e. they were not directly involved in the partnership. This was due to the liberal economic development and international trade policy of Indonesia that allowed large imports of cheaper yellow soybeans.

The critical performance indicators of the black soybean supply chain in the period 2008-2013 are shown in Table 1.

The aggregated performance figures disguise, however, variances and differences between cooperatives/ regions and farmers, because the agronomical conditions and soil quality vary widely between regions. This is an important point of concern for the Unilever Indonesia to minimize supply risks, also for the smallholders, such as in 2012. Production was exceptional higher (more one third) than forecast due to favorable weather conditions. Due to the fact that Unilever Indonesia is committed to buy all the produced black soybeans.

In 2013 Unilever Indonesia started with certification of black soybean farmers according companies Sustainable Agriculture Code (SAC) for black soybean production. This consisted of minimum sustainability standards regarding soil management, crop and animal husbandry, working conditions and environmental resources, which are applied to their suppliers and farmers who supply them. It was reported that in 2014 about $65 \%$ of the farmers were certified as SAC farmer.

Table 1. Performance indicators of the black soybean supply chain (2007-2012) (data provided by Unilever Foundation Indonesia).

Number of smallholders

Yield increase on average

Supply of total soybean demand

Return/costs-ratio per unit (pre-calculation 2013)
$5,000-8,300$

$360-700 \mathrm{~kg}$ per hectare

From 20 to $60 \%$

1.8 
The growth of number of smallholders participating the black soybean supply program, the yield increase on average and using pre-calculated return/cost-ratio (R/C-ratio) much larger than one for the pricing in the period 2007-2012, indicated that the black soybean case is a best practice empirical case in which Unilever Indonesia source effectively from smallholders.

\subsection{Indicators for smallholder livelihood improvement}

The impact of the applied black soybean upgrading program on smallholder livelihood was measured in two ways (paragraph 3.2).

First, Figure 3 shows the findings of the business model canvas exercise on the business model of black soybean farmers in Java as it was applied in a multi-stakeholders workshop.

The found business model canvas of black soybean smallholders clearly shows that the balance of the costrevenue structure of the farmers' business model was positive, which is an indicator of improved livelihood of the farmers. This was also confirmed by exploring the standard cost price calculation per unit of black soybean production used for the upgrading program. The outcome of the farmers' business model was that the calculated total production costs per kg of black soybean was more than $60 \%$ of the contract price (farm gate price) of the upgrading program (2013). This means that planting black soybeans was profitable for farmers according to the farmers' business model canvas exercise. Also during the farmers' workshop it was confirmed that the value of the black soybean as intercrop is that it is a secure and reliable source of income.

Second, Figure 4 shows that the average scores on the six inclusive business principles of the New Business Model Principles were positive. The conclusion is that the black soybean supply program was inclusive according to the New Business Model Principles.

We conclude that based on the positive outcomes of the two approaches the applied black soybean sourcing model indicates a positive impact on smallholder livelihood.

\begin{tabular}{|c|c|c|c|c|c|}
\hline \multirow[t]{2}{*}{$\begin{array}{l}\text { Partners } \\
\text { Partners provide: } \\
\text { Improved seeds } \\
\text { knowledge and } \\
\text { advice } \\
\text { - extension services } \\
\text { - financial services }\end{array}$} & \multicolumn{2}{|c|}{$\begin{array}{ll} & \\
& \\
\text { On-farm: } & \text { Off-farm } \\
\text { - Paddy } & \text { labor } \\
\text { - Black } & (30-50 \% \\
\text { soybean } & \text { of income })\end{array}$} & \multirow[t]{2}{*}{$\begin{array}{l}\text { Value } \\
\text { - Can provide } \\
\text { needed volumes } \\
\text { Reliable delivery } \\
\text { - Quality - dry, } \\
\text { clean, no brokens, } \\
\text { no insects }\end{array}$} & $\begin{array}{l}\text { Customer relationships } \\
\text { Relationships with } \\
\text { cooperatives are } \\
\text { contract based and involve } \\
\text { service provision. } \\
\text { Those who side-sell are } \\
\text { blacklisted. Relationships } \\
\text { with traders are formed } \\
\text { around prices negotiated } \\
\text { based on quality at harvest. }\end{array}$ & \multirow{2}{*}{$\begin{array}{l}\text { Customers } \\
\text { Unilever (for } \\
\text { cooperatives) } \\
\text { - Cooperatives } \\
\text { - Cattle farmers } \\
\text { (for rejected } \\
\text { beans, used for } \\
\text { cattle feed) } \\
\text { - Commodity } \\
\text { traders/brokers } \\
\text { at the local } \\
\text { market }\end{array}$} \\
\hline & \multicolumn{2}{|c|}{$\begin{array}{l}\text { - Land } \\
\text { - Labor } \\
\text { - Fertilizer } \\
\text { - Pesticides } \\
\text { - Social capital (groups) } \\
\text { - Water } \\
\text { - Information/knowledge } \\
\text { - Access to finance } \\
\text { - Equipment (need) }\end{array}$} & & $\begin{array}{l}\text { Channels } \\
\text { Farmers group: motifator } \\
\text { picks up harvest, they pay } \\
\text { fuel costs (or by bike } \\
\text { where close enough) } \\
\text { Market: bring it } \\
\text { themselves on public } \\
\text { transportation. }\end{array}$ & \\
\hline & & & & & \\
\hline
\end{tabular}

Figure 3. Business model of black soybean farmers in Java. 


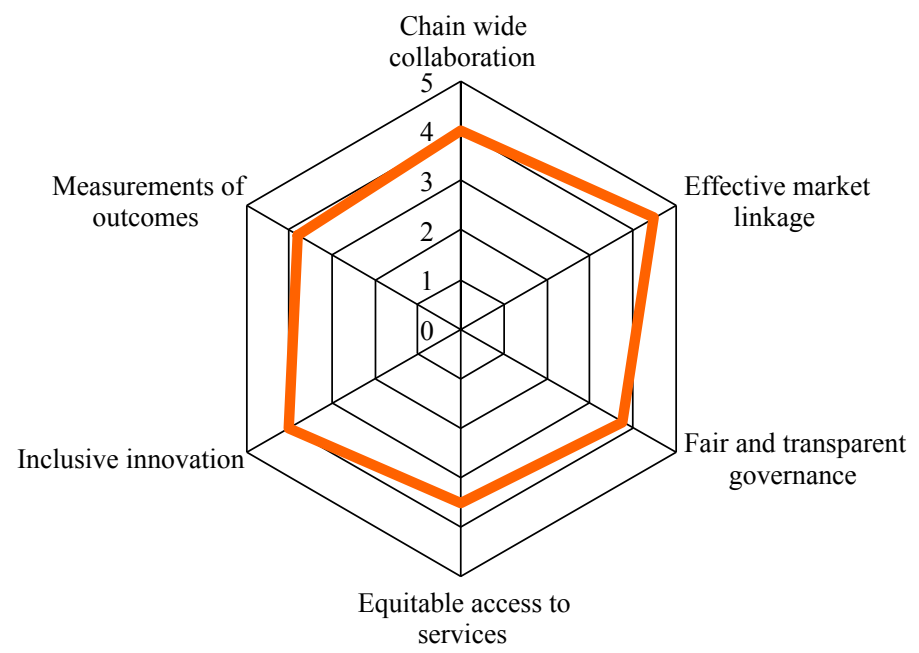

Figure 4. Inclusiveness of the black soybean business model in Java.

\subsection{Critical Success Factors of the black soybean supply chain}

The found CSFs of the black soybean supply chain in Java were:

- CSF 1: the selected farmers to grow black soybean are commercial/market-oriented small-scale paddy farmers.

We found that the characteristics of paddy farmers participating in the black soybean supply program meet the characteristics of commercial farms in tight value chains according Christen and Anderson (2013). The farm size of these farmers was 0.3 hectare on average. These farmers were likely to carry out a variety of other activities. They sold almost all of the paddy on the local market and used the dry season to plant an intercrop such as chili peppers, corn and groundnuts. They were members of a cooperative and participated in farmers' groups to cultivate black soybean as an intercrop.

- CSF 2: a long-term partnership was formed and a supplier development program was set up for upgrading.

We found that Unilever Indonesia has set up a partnership with selected farmers' cooperatives and seed suppliers and created a supplier development program to upgrade paddy farmers to cultivate black soybean. Unilever-Procurement led the buying processes while Unilever-CSR led the upgrading processes of the upgrading program, because upgrading small-scale paddy farmers was considered also a community development activity. This is consistent with the mission of Unilever-CSR, namely to strengthen the Unilever Indonesia's commitment to sustainable development to maintain a competitive edge.

- CSF 3: the governance structure of the black soybean supply chain is of a captive type based on a cooperative 'buyer-seller' relationship for black soybean supplier development.

The found governance structure of the black soybean supply chain can be classified according the classification of Gereffi et al. (2005) a captive type of governance, because the supply chain were locked in by Unilever Indonesia. The relationship between partners is based on a cooperative instead of a short-term transactional buyer-seller relationship, because of the long-term business perspective of the upgrading program. The communication within the black soybean partnership is a two-way and open system. There are regular meetings, visits to farmers during the planting period, and standard cost price calculations are used during the negotiations.

The local government did not participate in the black soybean partnership consisting of Unilever Indonesia, the cooperatives and the University of Gadja Mada (seed supplier). 
- CSF 4: cooperatives were empowered in order to strengthen the vertical coordination of the black soybean supply chain.

We found that the Cooperatives participating in the upgrading program of the black soybean supply chain were key contracting partners representing the member farmers. They play a central role in facilitating the flow of information, inputs, provision of upgrading support, and collection, sorting, storage and delivery of the contracted black soybeans. Farmers are aggregated in groups in order to communicate effectively and to lower transactional costs. Unilever Indonesia-CSR supports the improvement of management capabilities and the financial access of the cooperatives to strengthen vertical coordination in the black soybean supply chain.

- CSF 5: Unilever Indonesia offers a prepaid system before the harvest and a buying commitment of all produced soybeans.

The Unilever Indonesia offered price guarantee before planting and a buying commitment of all black soybeans harvested. Hence that Unilever Indonesia is not a financial institution. However, these buying conditions eased the credit demand and lowered the risks of the black soybean smallholder farmers. Farmers received $80 \%$ in advance on sales one month before the harvest, while the remaining $20 \%$ was paid within two weeks of delivery to the factory. This payment system combined with the buying commitment of the black soybeans produced eased the credit demand, lowered costs and reduced the risks of the black soybean smallholders. In addition, it was noticed in the farmers' workshop and during the interviews that this finance system was of great value especially to small-scale farmers because it is a secured source of income.

- CSF 6: presence of a clear smallholder sourcing strategy and commitment to secured sustainable black soybean supply combined with a proactive CSR strategy from a business perspective.

The CSR strategy was established to strengthen Unilever Indonesia's commitment to sustainable development in Indonesia. The final aim of this CSR strategy is to maintain competitive advantage of Unilever Indonesia, while continuously ensuring the business commitments to community building, creation of employment and wealth, as well as caring for the environment. In practice this means that Unilever Indonesia-CSR supports the sustainability performance of the projects of the business units of Unilever Indonesia. The development of an alternative black soybean supply chain fits into the sustainable business development approach of the Unilever Indonesia.

- CSF 7: use of cross-functional sourcing teams consisting of Procurement and CSR with clear division of tasks, resources and incentives for effective black soybean supplier development, but both are focus on the same Unilever Indonesia inclusive goal.

Within the Unilever Indonesia, close coordination between Unilever Indonesia-CSR and Unilever Indonesia-Procurement staff enabled them to run the upgrading program in a smooth way. Unilever Indonesia-CSR played a program management role in the upgrading processes from input supply to the sorting out stage of the soybeans harvested. Procurement steered buying processes in the collection and logistics of the soybeans from the cooperatives to the soy sauce factory, and the payment of the delivered black soybeans. Unilever Indonesia-Procurement as well as the Unilever Indonesia-CSR were focused on the same strategic corporate goal, i.e. the development of a sustainable smallholder supply chain to strengthen Unilever Indonesia market position in Indonesia and contributing to smallholders' livelihood. There was a clear division of tasks between the Unilever Indonesia-CSR, which is a companies' foundation, and the Unilever Indonesia-Procurement, which is a department of Unilever Indonesia. However, both had compatible tasks, complementary competences, resources/ funds and incentives, and there was an open communication and understanding between them.

The overall finding of the case study is that the CSFs in the black soybean case were in line with the CSFs of the 3S-model. However, differences found were the role of Unilever Indonesia in providing affordable farm financing (CSF 5) and the business form Unilever Indonesia-CSR. 


\subsection{Matching of the black soybean map with the 3S-model frame}

To illustrate the applicability and the dynamics of the 3S-model we have matched the empirical black soybean supply chain map (Figure 2) with the of the 3S-model (Figure 1). The result is shown in Table 2. We conclude that the black soybean supply map is in general in line with the framework (building blocks) of the 3S-model with related CSFs.

\section{Discussion and conclusions}

The purpose of present article was to explore the applicability and the dynamics of the sustainable sourcing model for sustainable smallholder supply (3S-model) based on a best practice case as empirical background. In this model the business perspective (to secure stable access to sustainable smallholders' commodity supply) and CSR perspective (improvement of smallholder livelihood) are integrated.

The overall finding of the study is that the dynamics of the Unilever case can be understood with the help of the 3S-model. Similarities include the use of a partnerships model for upgrading, a captive governance structure, and the existence of a clear proactive and committed corporate sustainable smallholder sourcing strategy. At the same time we also found differences regarding the role of the ULI in farm financing, the business form of suppliers and the cross functional sourcing team that influence the concept of the 3S-model. The following lessons are learned from these differences.

First, regarding building partnerships for upgrading (CSF 2): although the 3S-model for sustainable smallholder sourcing has a business perspective, input suppliers can also be public organizations instead of just private companies alone. We think that in the pilot and start-up phase of a smallholder supply development program, this isn't a constraint, because of the supportive character of the program. However, in the scale up phase of the supply chain, the limits of a public organization in a business setting could be more pressing, because of the non-commercial orientation of the public organization to grow together with the business in a competitive global market environment (e.g. provision of long term investment capital and profit making).

Table 2. Black soybean supply chain map according to the $3 \mathrm{~S}$-model. ${ }^{1}$

\begin{tabular}{|c|c|}
\hline Building blocks of the 3S-model & Black soybean supply chain map \\
\hline F\&A MNE & $\begin{array}{l}\text { ULI represented by: } \\
\text { - Procurement (buying black soybeans from cooperatives). } \\
\text { - ULI-CSR (a company's foundation, leading upgrading } \\
\text { processes). }\end{array}$ \\
\hline Intermediary & $\begin{array}{l}\text { Cooperatives: representing farmers in the partnership, organizing } \\
\text { member farmers for production, facilitating upgrading and } \\
\text { delivering processes of black soybean. }\end{array}$ \\
\hline Smallholders & $\begin{array}{l}\text { Commercially oriented small-scale paddy farmers growing black } \\
\text { soybeans on a contractual base. }\end{array}$ \\
\hline Partnership model & $\begin{array}{l}\text { Consisting of MNE, cooperatives and seed supplier (a } \\
\text { university), using a farmer development program for upgrading. }\end{array}$ \\
\hline $\begin{array}{l}\text { Government, NGOs, public bodies, private } \\
\text { foundation, social investors: (control variables) }\end{array}$ & $\begin{array}{l}\text { - Government has been involved on arm's length. } \\
\text { - NGO empowered women group. } \\
\text { - Local SME's provided farm services. }\end{array}$ \\
\hline Smallholder livelihood improvement & Positive indication (e.g. R/C-ratio>one) \\
\hline
\end{tabular}


Second, regarding providing access to finance to smallholders (CSF 5): F\&A MNEs can play an important role to lower financing cost and risks for smallholders by offering buying commitments and price guarantees and down payments before planting, although they are no credit institutions themselves. These facilities can attract rural banks to provide farm financing to smallholders, because such buying guarantees lower financing risks for bank credits (smallholders in developing regions often miss reliable collaterals, land titles and professional book keeping over a long period of time).

Moreover, this type of producers' contractual financial relationship between MNE - Intermediary Smallholders in the value chain could also provide opportunities for value chain financing by banks. F\&A MNEs are then taking the lead (as lead contractor) in the value chain in the farm financing. The concept of value chain financing can be defined as financial services and products flowing to and/or through value chain participants in order to address and alleviate driving constraints to growth and competiveness of that value chain (e.g. Miller and Jones, 2010).

Third, regarding the sourcing organization of the F\&A MNE for governing long-term smallholder supplier development programs effectively (CSF 7): because there are process-related, cognitive, structural and incentive-related challenges to overcome, one of the most critical points is the refining of the traditional role and capabilities of Unilever Indonesias' CSR and Procurement departments and their activities within the F\&A MNE. The use of cross-functional teams consisting of Procurement and CSR staff and resources (CSF 7 of the 3S-model) as we found in the black soybean case. In this case, Unilever Indonesia-CSR related activities are employed via the company's foundation, i.e. an independent non-profit organization with a corporate sustainability mission and resources, that works at the Bottom of the economic Pyramid to strengthens a company's license to operate, rather than a department of the core business organization of F\&A MNEs. The advantage of this internal organization within F\&A MNEs is that CSR goals can be combined with core business sourcing goals of the F\&A MNE, i.e. to make a company (more) business inclusive.

Based on the lessons learned from the black soybean case study the following CSFs have been sharpened:

- CSF 5: 'Providing access to finance to smallholder' has been change into 'Lowering financing costs and risks of smallholders, because MNEs are no credit institutions. However, they can offer to buy the produce at a guaranteed price and do down payment before planting to farmers to ease smallholders' financing needs.

- CSF 7: 'Use of cross-functional sourcing teams' has been changed into 'Use of cross-functional sourcing teams that combine corporate sourcing and CSR goals', because a common focus on the corporate sourcing goals of the team is more important than the organization a team member.

However, there are questions to be discussed left. First, despite a positive indication of the contribution to the smallholder sourcing model livelihood, the question remains whether smallholders do get an equitable piece of the cake, i.e. do they get the real price for their produce that covers at least all costs and risks? A clear answer to this question can hardly be given because of several reasons, for instance because of the business development and learning character of supplier development programs. Primary sources for raising farm income are improvement of the productivity (higher yields per hectare) and product quality (higher price). Moreover, smallholders in developing economies are mostly not familiar with cost price calculations and bookkeeping, and lack price and market information or are surrendered to the practices of a middlemen (e.g. London et al., 2010).

Second, the question is what Unilever would do in case there is an excessive supply of black soybeans? The consideration of Unilever to develop an own smallholder black soybean supply chain has been driven by the expectation that demand of black soybean will exceed supply on the one hand. On the other hand, it was an opportunity to express Unilever's CSR commitments in community development building, creating employment and livelihood improvement of small-scale farmers in Indonesia (Urip, 2010). Accordingly, Unilever offered price guaranty before planting and a buying commitment of all black soybeans harvested to 
farmers. The agreed terms were written down in a Memorandum of Understanding. These two considerations compelled Unilever to fulfill the obligations avoiding reputational risks.

However, in 2012 the production of the contracted black soybeans was 35\% higher than the forecast, due to favourable weather conditions. Due to the fact that Unilever Indonesia was committed to buy all the harvested black soybeans the storage capacity proved insufficient and question raised about the accuracy of the production forecasting system.

The third questions is, what will happen with the black soybean sourcing model in case of severe downturns of Unilever or in case of crop failure because severe drought or extreme soya price falls? On the one hand, there is no guaranty that Unilever will never change it strategy, such as in case of a downturn, because firms need to be profitable in order to survive and grow in a challenging global food system. On the other hand, the best guaranty that F\&A MNE's take their responsibility serious is the level of their CSR commitment. In case of Unilever, the company has a proactive CSR strategy, implying that is has the capacity, procedures, arrangements, behavior patterns, sustainable codes and standards to anticipate on social issues, and a committed top management (Van Tilburg et al., 2012). This is a precondition for long-term investment in smallholder supplier development programs in order to secure a (long-term) sustainable and more equitable commodity supply from a business perspective (CSF 6).

Although we have illustrated in this study that from a business perspective MNEs can include smallholders in a sustainable and more equitable way in high value-adding supply chains from a business perspective, the overall effect of F\&A MNEs in solving global food security and sustainable development challenges must not be overestimated. Constraints are among other things their short-term commercial and business model orientation, and their relatively small scale in the global food system compared to the estimated 200 million small-scale commercially oriented farmers operating at the Bottom of the Pyramid (Christen and Anderson, 2013), i.e. F\&A MNEs cannot do it alone (e.g. World Economic Forum, 2011).

Nonetheless, we believe that the fact that the value chain analysis of the black soybean supply chain is commissioned by both an international NGO (OXFAM) and a corporate actor (Unilever), provides a unique case for studying integration of business and CSR perspectives in smallholder inclusion in high value-adding supply chains, which is the underlying basic principle of the 3S-model with CSFs and drivers of supply chain dynamics. The added value of this research is, especially to management scholars, that the black soybean case illustrates that MNEs can include smallholders in a sustainable and more equitable way in high value adding supply chains. It can help in (re-)designing (conventional) sustainable smallholder sourcing strategies.

However, there are limitations to this study because the findings were based on a single case. Food sectors, geographical conditions, the political context and sourcing strategies of F\&A MNEs may differ. Accordingly, we recommend further case study research in order to further confirm, modify, or fine-tune the 3S-model.

\section{Acknowledgements}

Authors are indebted to Unilever Penduli Indonesia and Procurement PT Unilever Indonesia for facilitating the field research. They want to specially acknowledge the interviewees, Andre Setiawan, Syaiful Hakim, Sinta Kaniawati, Theresa Wuryanti and Hanah Schiff (epven, Ltd.) for their kind cooperation. They are also grateful to the Sunrise 2.0 project team, especially to Justin Tait (Sunrise), Ximing Hu (Unilever) and Juni $\mathrm{Sul}$ (Oxfam) that commissioned the value chain analysis.

\section{Supplementary material}

Supplementary material can be found online at https://doi.org/10.22434/IFAMR2016.0171.

Methods S1. Topics of the semi structured interviews. 


\section{References}

Alvarez, G., C. Pilbeam and R. Wilding. 2010. Nestlé Nespresso AAA sustainable quality program: an investigation into the governance dynamins in a multi-stakeholder supply chain network. Supply Chain Management 15(2): 165-182.

Blackman, A. and J. Rivera. 2011. Producer-level benefits of sustainable certification. Conservation Biology 25: $1176-1185$.

Blok, V., A.R. Sjauw-Koen-Fa and S.W.F. Omta. 2013. Effective stakeholder involvement at the base at the pyramid: the case of Rabobank. International Food and Agribusiness Management Review 16(A): 39-44.

Busch, L. and C. Bain. 2004. New! Improved? The transformation of the global agrifood system. Rural Sociology 69(3): 321-346.

Caroll, A.B. 1979. A three-dimensional conceptual model of corporate performance. Academy of Management Review 4(4): 497-505.

Carter, C.R. and D.S. Rogers. 2008. A framework of sustainable supply chain management: moving toward new theory. International Journal of Physical Distribution and Logistics Management 38(5): 360-387.

Chalmers, G., M.D. Wenner, P. Tiffen and E. Gálvez. 2006. Lessons learned in agricultural value chain financing. Paper presented on the seminar 'Agricultural value chain finance'. FAO, and Academia de Centroamérica, San José, Costa Rica.

Chambo, S.A. 2009. Agricultural co-operatives: role in food security and rural development. UN expert group meeting on co-operatives April 28-30 2009, UN, New York, USA. Available at: http://tinyurl. $\mathrm{com} /$ yanfdnud.

Chen, I.J. and A. Paulraj. 2004. Towards a theory of supply chain management: the constructs and measurements. Journal of Operations and Management 22: 119-150.

Christen, R.P. and J. Anderson. 2013. Segmentation of smallholders households: meeting the range of financial needs in agricultural families. Forum note 85, Consultative Group to Assist the Poor (CGAP), Washington, WA, USA.

Dartanto, T. and M. Usman. 2011. Volatility of world soybean prices, import tariffs and poverty in Indonesia: a CGE-Microsimulation analysis. The Journal of Applied Economic Research 5: 139-165.

Dragusanu, R., D. Giovannucci and N. Nunn. 2014. The economics of fair trade. Journal of Economic Perspectives 28(3): 217-236.

Driedonks, B.A., J.M.P. Gevers and A. van Weele. 2014. Success factors for sourcing teams: how to foster sourcing team effectiveness. European Management Journal 32(2): 288-304.

Dyer, J.H. and H. Singh. 1998. The relational view: cooperative strategy and sources of inter organizational competitive advantage. Academy of Management Review 23(4): 660-679.

FAO. 2009. Global agriculture towards 2050. High-level expert forum 12-13 October. FAO, Rome, Italy.

Gereffi, G., J. Humphrey and T. Sturgeon. 2005. The governance of global value chains. Review of International Political Economy 12(1): 78-104.

Gold, S., R. Hahn and S. Seuring, 2013. Sustainable supply chain management in the 'Base of the Pyramid' food projects - A path to triple bottom line approaches for multinationals? International Business Review 22: 784-799.

Hahn, R. and S. Gold. 2013. Resources and governance in 'base of the pyramid'-partnerships: assessing collaborations between business and non-business actors. Journal of Business Research 67: 1321-1333.

Hahn, C.K., C.A. Watts and K.Y. Kim. 1990. The supplier development program: a conceptual model. Journal of Purchasing and Materials Management 26: 2-7.

Hasibuan-Sedyono, C. 2010. Growing together in partnership: the case of Unilever and the black soybean farmers in Indonesia, Binus Business School, Global Compact Network, Jakarta, Indonesia.

Henson, S. and J. Humphrey. 2009. The impacts of private food safety standards on the food chain and on public standards-setting processes. Paper prepared for FAO/WHO 2009. Available at: http://tinyurl. com/yceh5wtz.

Humphrey, J. 2004. Upgrading in global value chains. Working Paper No 28. International Labour Office, Geneva, Switzerland. 
Humphrey, J. and H. Schmitz. 2002. How does insertion in global value chains affect upgrading in industrial clusters. Regional Studies 36(9): 1017-1027.

IFC and GPFI. 2011. Scaling up access to finance for agricultural SMEs policy review and recommendations. IFC, Washington, WA, USA.

Jaffee, S. and S. Henson. 2004. Standards and Agro-food exports from developing countries: rebalancing the debate. World Bank Policy research working paper 3348. Available at: http://tinyurl.com/ybyorlcf.

Krause, D.R. and L.M. Ellram. 1997. Critical elements of supplier development: the buying perspective. European Journal of Purchasing and Supply Chain management 3(1): 21-31.

Landros, R. and R.M. Monczka. 1989. Cooperative buyer/seller relationships and a firm's competitive posture. Journal of Purchasing and Material management 25(3): 9-18.

London, T., R. Anupindi and S. Sheth. 2010. Creating mutual value: lessons learned from ventures serving base of the pyramid producers. Journal of Business Research 63: 582-594.

Maignan, I., B. Hillebrand and D. McAlister. 2002. Managing socially-responsible buying: how to integrate non-economic criteria into the purchasing process. European Management Journal 20(6): 641-648.

Miller, C. and L. Jones. 2010. Agricultural value chain finance: tools and lessons. Food and Agriculture Organization of the United Nations and Practical Action Publishing, Rome, Italy and Warwickshire, UK.

Mohr, J. and R. Spekman. 1994. Characteristics of partnership success: partnership attributes, communication behavior, and conflict resolution techniques. Strategic Management Journal 15: 135-152.

Monczka, R.M., K.J. Petersen, R.B. Handfield and G.L. Ragatz. 1998. Success factors in strategic supplier alliances: the buying company perspectives. Decision Sciences 29(3): 553-577.

Olsen, M. and E. Boxenbaum. 2009. Bottom-of-the-Pyramid: organizational barriers to implementation. California Management Review 51(4): 100-125.

Onumah, G., E. Junior, R. Davis, U. Kleih and F.J. Proctor. 2007. Empowering smallholder farmers in markets: changing agricultural marketing systems and innovative responses by producers organizations. ESFIM Working Paper 2. IFAD, CTA and AgriCord, Rome, Italy.

Perez-Aleman, P. and M. Sandilands. 2008. Building value at the top and bottom of the global supply chain: MNC-NGO partnership and sustainability. California Management Review 51(1): 24-49.

Reardon, T., C.B. Barrett, J.A. Berdegué and J.F.M. Swinnen. 2009. Agrifood industry transformation and small farmers in developing countries. World Development 37(11): 1717-1727.

Riisgaard, L., S. Bolwig, F. Matose, S. Ponte, A. du Toit and N. Halberg. 2010. Integrating poverty and environmental concerns into value-chain analysis: a strategic framework and practical guide. Development Policy Review 28(2): 195-216.

Rivera-Santos, M. and C. Rufin. 2010. Global village vs small town: understanding networks at the base of the pyramid. International Business Review 19: 126-139.

Rossignoli, C.M. and R. Moruzzo. 2014. Retail power and private standards in the agri-food chain. Agroecology and Sustainability Food Systems 38: 1108-1124.

Ruben, R. and R. Fort. 2011. The impact of fair trade certification for coffee farmers in Peru. World Development 40(3): 570-582.

Rueda, X. and E.F. Lambin. 2013. Responding to globalization: impact of certification on Colombia smallscale coffee growers. Ecology and Society 18(3): 21.

Sjauw-Koen-Fa, A.R. 2010. Sustainability and security of the global food supply chain. Economic Research Department of the Rabobank Group, the Netherlands. Available at: https:/www.academia. edu/16331687.

Sjauw-Koen-Fa, A.R. 2012. Framework for an inclusive food strategy. Co-operatives key for smallholder inclusion into value chains, Economic Research department, Rabobank Group. Available at: http:// tinyurl.com/ycbgve74.

Sjauw-Koen-Fa, A.R., V. Blok and S.W.F. Omta. 2016. Critical success factors for smallholder inclusion in high value-adding supply chains by Food and Agribusiness Multinational Enterprises. International Food and Agribusiness Management Review 19(1): 83-112.

Spence, L. and M. Bourlakis. 2009. The evolution from corporate social responsibility to supply chain responsibility: the case of Waitrose. Supply Chain Management 14(4): 291-302. 
Tait, J. 2015. Project Sunrise: final report. Unilever and Oxfam UK. Available at: http://tinyurl.com/y8h4tsqf.

Torero, M. 2011. A framework for linking small farmers to markets. Conference on 'New directions for smallholder agriculture' 24-25 January 2011, IFAD, Rome, Italy. Available at: http:/tinyurl.com/ yarnfgzz.

Trent, R.J. and R.M. Monczka. 1994. Effective cross-functional sourcing teams: critical success factors. International Journal of Purchasing and Material Management 30: 2-11.

Trent, R.J. and R.M. Monczka. 2002. Pursuing competitive advantage through integrated global sourcing. Academy of management executive 16(2): 66-80.

Trienekens, J.H., P.M. Wognum, A.J.M. Beulens and J.G.A.J. van de Vorst. 2012. Transparency in complex dynamic food supply chains. Advanced Engineering Informatics 26: 55-65.

Urip, S. 2010. CSR strategies: corporate social responsibility for competitive edge in emerging markets. John Wiley (Asia) Pte. Ltd., Singapore.

Van Tilburg, R., R. van Tulder, M. Francken and A. da Rosa. 2012. Duurzaam ondernemen waarmaken, Stichting Management Studies, van Gorcum, Assen, the Netherlands.

Watts, C.A., K.Y. Kim and C.K. Hahn. 1995. Linking purchasing to corporate competitive strategy. Journal of Supply Chain Management: 31: 2-8.

World Economic Forum. 2011. Realizing a new vision for agriculture: a road map for stakeholders. WEF, Geneva, Switzerland. 
